\title{
Planting Dates and Harvesting Stages Influence on Maize Yield under Rain-Fed Conditions
}

\author{
Dolapo Bola Akinnuoye-Adelabu ${ }^{1} \&$ Albert Thembinkosi Modi $^{1}$ \\ ${ }^{1}$ Crop Science, School of Agricultural, Earth and Environmental Sciences, University of KwaZulu-Natal, \\ Scottsville, Pietermaritzburg, South Africa \\ Correspondence: Dolapo Bola Akinnuoye-Adelabu, Crop Science, School of Agricultural, Earth and \\ Environmental Sciences, University of KwaZulu-Natal, P/Bag X01, Scottsville 3209, Pietermaritzburg, South \\ Africa. Tel: 27-849-861-558. E-mail: solakinns@yahoo.com
}

$\begin{aligned} & \text { Received: September 27, } 2016 \quad \text { Accepted: November 5, 2016 Online Published: August 15, } 2017 \\ & \text { doi:10.5539/jas.v9n9p43 }\end{aligned}$ URL: https://doi.org/10.5539/jas.v9n9p43

This research was financed by the National Research Foundation of South Africa through the Innovation Doctoral Scholarship (Grant UID: 90406).

\begin{abstract}
Understanding the challenges associated with variation in weather conditions and stages of maturity in maize are essential for farmers to achieve continuous production under climate changes. This research evaluated the interactive effect of planting date and stages of maturity at harvest on maize yield (Zea mays L.). Field trials were conducted during the 2014/15 and 2015/16 seasons at university of KwaZulu-Natal research farm Pietermaritzburg South Africa. Planting dates comprised of early (November), mid (December) and late planting dates (January). While, harvesting occurred at milk stage, dent stage and physiological maturity. A split plotdesign with four replications was used. The main plot and sub-plot consisted of planting dates and harvesting stages respectively. Response of maize to planting dates and harvesting stages was determined by variables of plant physiological growth and yield parameters. Significant differences in growth and physiological parameters were more obvious in 2015/16 season which was a drier season than 2014/15. Early and mid-planting had positive effect on parameters measured at both seasons. However, mid planting date favoured maize growth and yield more in drier season. The interaction of planting dates and harvesting stages significantly influenced grain yield, thousand seed weight, ear length and diameter. Thousand seed weight, ear length and diameter obtained at dent stage under mid planting outperformed its counterpart from physiological maturity under which late planting. With the increase in climate variability there is high risk that maize planted lately would have lower yield irrespective of its planting dates and might not attain physiological maturity. However, maize harvested at dent stage under early and mid-planting dates gave substantially high yield.
\end{abstract}

Keywords: maturation, production, season, weather

\section{Introduction}

The weather conditions at the time of planting have a profound influence on the potential profitability of maize especially under rain-fed cultivation which is common practice by small holder farmers. Hence, planting date is one of the most important management practices that influence the resultant crop yield through seedling establishment and development. Planting date has direct influence on day and night temperature, light intensity, photoperiod and soil moisture which affect crop growth duration and harvesting period. However, optimal planting dates varies across region and differences in planting dates expose crop to different stress factors. Existing body of knowledge have shown that maize yield potential reduced with delay in planting beyond the optimum planting window for a given environment (Coulter, 2012; Kgasago, 2006; Nafziger, 2008). In South Africa, early planting usually commences around October/November, though optimal planting widow occurs in late spring/early summer (November/December) while planting can be extended to January. The current drastic variability in weather conditions may cause shift in optimal planting date widow, thereby leading to delay in planting date. The number of suitable days can vary greatly from year to year. 
Rainfall patterns and other weather conditions associated with different planting dates have a modifying effect on length of the growing season, maize development and harvesting period (Beiragi et al., 2011). Maize yield response to planting date is very similar in different years and locations attributing yield benefits to early planting (Good et al., 2015; Nafziger, 2008). Furthermore, maize hybrids respond differently to planting dates (Darby \& Lauer, 2002). Each maize hybrid has an optimum planting date and any deviation from optimal planting date may negatively influence the growth duration and the yield (Sárvári \& Futó, 2000). However, the number of growing degree days (GDD) needed for maize hybrids to reach various developmental stages is fairly uniform across environments (Hoegemeyer, 2013).

Maize SC701 cultivar is one of the commonly southern African grown hybrids. The cultivar's desired traits were its large ear size, long shelf life high yield and moderate drought tolerance (ARC, 2014). It is a late maturing cultivar which requires an average of 1028 GDD from emergence (VE) to physiological maturity (R6) and an average of $6.4 \mathrm{~mm} /$ day of water from 12 leaf stage to full dent stage (Darby \& Lauer, 2002). The relationship between the maturity length of a maize hybrid and its GDD accumulations at a given location determine their optimal harvesting period and its adaptability. Intensively studies have been carried out on the effect of harvesting stages on maize yield and agreed that the optimal time to harvest maize is when close to its physiological maturity (Daynard, 1972; Henning et al., 2011; Jacob Junior et al., 2014). However, consideration was not even under extreme or adverse weather conditions which may prevent the crop from attaining physiological maturity. Nielsen (Bob) (2013) reported that approximately yield losses due to adverse condition on the field range from 50,39 , and $12 \%$ when harvesting occurs at $\mathrm{R}_{4}$ (dough), $\mathrm{R}_{5}$ (full dent), and half-milk line stages of kernel development respectively.

The relationship between the time of planting and its harvesting stage may bring possibility of higher yield during extreme temperature and rainfall since maize development varies with ambient temperature from emergence to physiological maturity. Anwar et al. (2015) explained that extreme temperatures caused developmental shifts and disrupting reproduction processes. Also, late planting maize may experience cooler conditions during its early vegetative growth stage and extended towards grain filling stage which may lengthens the grain filling period. However, if water stress is severe, kernel may store relatively lesser sugar, resulting in lower kernels weight and yields.

The relationships between earlier harvested maize before reaching physiological maturity and planting date need to be considered to prevent total yield loss under adverse weather conditions. Since future weather conditions are not easy to predict, management strategies to improve yield of earlier harvested maize are required to enhance maize farmers with high production efficiency. The understanding of the environmental and agronomic responses of maize hybrids will help to develop appropriate mitigation measures during adverse weather conditions

The specific importance of planting dates and harvesting stages of this commonly grown SC701 cultivar is limited. Also, little is known about the relationship of planting date and harvesting stages of SC701 on its yield under varying environmental conditions. Therefore, this research is given by the need to substantially increase the efficiency of maize production during adverse weather conditions. Hence, the present study was conducted to evaluate the combine effects of planting dates and harvesting stages on yield of SC701 maize cultivar. It compares the efficiency of maize harvested at different maturity stage under different planting dates.

\section{Materials and Methods}

\subsection{Experimental Site Description}

Field trials were conducted at the university of KwaZulu-Natal's Ukulinga research farm $\left(29^{\circ} 37^{\prime} \mathrm{S}\right.$; $30^{\circ} 16^{\prime} \mathrm{E}$; 775 m a.s.1.) in Pietermaritzburg South Africa over two summer seasons (2014/15 and 2015/16). Ukulinga is classified as semi-arid with annual rainfall ranging from $644-838 \mathrm{~mm}$ almost $80 \%$ occurs around October to April while $20 \%$ occurs during the winter months and mean annual temperatures of $18.4{ }^{\circ} \mathrm{C}$ (Smith, 2006). The area experiences warm to hot summers and mild winters with occasional frost and mean annual temperature of $18.4^{\circ} \mathrm{C}$. The soil at Ukulinga was classified as Sterkspruit Smithfield characterised as shallow brown acidic clayey soils with low organic matter (SCWG, 2009). The amount of nutrient base is quite low owing to low Cation Exchange Capacity contributing to nitrogen and phosphorous and deficiencies (FAO, 2015). Results of soil chemical properties showed that the carbon (\%) for the top $0.2 \mathrm{~m}$ layer was $2.3 \%$ while $\mathrm{N}$ was $0.3 \%$ (Table 1).

Foundation seeds of SC701 maize cultivar of uniform size was sourced from McDonalds Seed Company, in KwaZulu-Natal, South Africa were planted during 2014/15 season while its progeny seed was planted in 2015/16 season. Foundation seed was used to eliminate any previous environmental influence on the seed and to have full 
parental history. Early planting commenced when soil field capacity is at maximum which was on $24^{\text {th }}$ and $19^{\text {th }}$ November, mid-planting was on $12^{\text {th }}$ and $17^{\text {th }}$ December and late planting date was on $21^{\text {st }}$ and $27^{\text {th }}$ January for 2014/2015 and 2015/ 2016 seasons respectively.

Table 1. Physiochemical properties of soil at $(0-20 \mathrm{~cm})$ before setting up the experiments at Ukulinga site in 2014/15 and 2015/16 planting seasons

\begin{tabular}{|c|c|c|c|c|c|c|c|c|c|c|c|c|c|c|}
\hline & $\begin{array}{l}\text { Density } \\
(\mathrm{mg} / \mathrm{L})\end{array}$ & $\begin{array}{l}\mathrm{P} \\
(\mathrm{mg} / \mathrm{L})\end{array}$ & $\begin{array}{l}\mathrm{K} \\
(\mathrm{mg} / \mathrm{L})\end{array}$ & $\begin{array}{l}\mathrm{N} \\
(\%)\end{array}$ & $\begin{array}{l}\mathrm{Ca} \\
(\mathrm{mg} / \mathrm{L})\end{array}$ & $\begin{array}{l}\mathrm{Ph} \\
(\mathrm{KCl})\end{array}$ & $\begin{array}{l}\mathrm{Mg} \\
(\mathrm{mg} / \mathrm{L})\end{array}$ & $\begin{array}{l}\mathrm{Mn} \\
(\mathrm{mg} / \mathrm{L})\end{array}$ & $\begin{array}{l}\mathrm{Cu} \\
(\mathrm{mg} / \mathrm{L})\end{array}$ & $\begin{array}{l}\text { Exch. } \\
\text { Acidity } \\
(\mathrm{Cmol} / \mathrm{L})\end{array}$ & $\begin{array}{l}\text { Total } \\
\text { cations } \\
(\mathrm{Cmol} / \mathrm{L})\end{array}$ & $\begin{array}{l}\text { Clay } \\
(\%)\end{array}$ & *Soil texture & $\begin{array}{l}\text { Organic } \\
\text { Carbon } \\
(\%)\end{array}$ \\
\hline $1^{\text {st }}$ season & 1.18 & 38 & 424 & 0.23 & 1739 & 4.45 & 581 & 27 & 10.8 & 0.18 & 14.72 & 31 & Clayey loam & 2.30 \\
\hline $2^{\text {nd }}$ season & 1.13 & 32 & 427 & 0.23 & 1851 & 4.80 & 683 & 29 & 8.2 & 0.11 & 16.20 & 31 & Clayey loam & 2.23 \\
\hline
\end{tabular}

Note. * USDA soil classification system.

\subsection{Crop Management}

Land preparation involved ploughing, disking and rotovating to achieve fine tilth. The herbicides 2-chloro-2-6diethyl-N-(methoxymethyl) acetanilide (alachlor) was broadcast pre-emergence at rates of $2.8 \mathrm{~kg} / \mathrm{ha}$. Prior to planting, soil sampling was collected from top soil $(0-20 \mathrm{~cm})$ randomly and analysed for selected physicochemical properties. Based on soil fertility results, $200 \mathrm{~kg} / \mathrm{ha}$ of urea $(\mathrm{N})$ and $20 \mathrm{~kg} / \mathrm{ha}$ of triple super phosphate granule fertilizer $(46 \% \mathrm{P})$ were applied. For $\mathrm{N}$ fertilizer, each level was split into two equal parts (half was applied at planting and another half at 8 weeks after planting. Weeds were controlled manually by hand hoeing. Pesticide was sprayed to control the infestation of insect pests.

\subsection{Experimental Design and Layout}

At each planting season, the experiment was a split-plot design with planting dates being the main plot and sub-plot comprised of the harvesting stages with four replications. Smith (2006) recommended a plant density of 30,000 plants/ha for maize under low $(700 \mathrm{~mm})$ rain-fed conditions. This current research had the final plant density to be 26,667 plants/ha. The experimental plot of each planting date was made of six rows (planted 750 $\mathrm{mm}$ apart and $500 \mathrm{~mm}$ within rows). The sampling unit was made of the four inner rows.

\subsection{Data Collection}

\subsubsection{Plant Growth Parameters}

Observation on growth parameters viz. leaf number (LN) and plant height (PHT) were taken at eight $\left(\mathrm{V}_{8}\right)$, ten $\left(\mathrm{V}_{10}\right)$ and tasseling stage $\left(\mathrm{V}_{\mathrm{T}}\right)$ visible leaves from the base of the plant to the tip of the tallest leaf and recorded in $\mathrm{cm}$. Six randomly selected plants from penultimate rows of each plot were measured for various growth observations.

Leaf area index (LAI) was measured starting from $\mathrm{V}_{\mathrm{T}}$ at fortnightly interval using AccuPAR/LAI Ceptometer (Model LP-80, Decagon devices Inc,) which used the following formula described by Pierce and Running (1988):

\subsubsection{Physiological Parameters}

$$
\mathrm{LAI}=\frac{\text { Total leaf area of plant }}{\text { Ground area covered by a plant }}
$$

Physiological parameters of the plants were measured fortnightly as the plant shifted to tasseling stage $\left(\mathrm{V}_{\mathrm{T}}\right)$. Chlorophyll content index (CCI) was measured using a portable SPAD meter (Model SPAD-502-PLUS chlorophyll meter, Konica Minolta, USA) on the adaxial surface of the ear leaf. While, stomatal conductance $\left(\mathrm{g}_{\mathrm{s}}\right)$ was measured from the abaxial surface during midday (1200-1400 hrs.) using a steady state leaf porometer (Model SC-1, Decagon Devices, USA).

Time to $50 \%$ tasseling (TTT) and silking (TTS) were taken as number of calendar days taken to reach $50 \%$ tasseling and silking from the date after planting. It was recorded based on the appearance of tassels and silks in $50 \%$ of the plants in each plot and expressed in days and later converted to thermal time using method described by McMaster and Wilhelm (1997): 


$$
\mathrm{GDD}=\frac{\left(\mathrm{T}_{\max }+\mathrm{T}_{\min }\right)}{2}-\mathrm{T} \text { base }
$$

Where,

GDD = growing degree days $\left({ }^{\circ} \mathrm{cd}\right), \mathrm{T}_{\max }$ and $\mathrm{T}_{\min }=$ maximum and minimum temperatures, respectively, and $\mathrm{T}_{\text {base }}$ $=$ base temperature. If $\operatorname{Tmax}<\mathrm{T}_{\text {base }}$ then $\mathrm{T}_{\max }=\mathrm{T}$ base and if $\mathrm{T}_{\min }<\mathrm{T}_{\text {base }}$ then $\mathrm{T}_{\min }=\mathrm{T}_{\text {base }}, \mathrm{T}_{\text {base }}=10^{\circ} \mathrm{C}$.

\subsection{Yield and Yield Components}

A standardized maize development stage system was used to identify the harvesting stages (Ritchie et al., 1992). Maize ears were harvested at three stages of development, milk stage $\left(\mathrm{R}_{3}\right)$ which is 18 days after silking (DAS), dent stage $\left(R_{5}\right)$ which is 42 DAS and physiological maturity $\left(R_{6}\right)$ which is 58 DAS. At each harvest six ears were randomly selected in each plot and first ear from the top of the plant was harvested by hand.

The seed moisture content (SMC) was determined by dry weight basis and was calculated by the following formula:

$$
\mathrm{SMC}=\frac{\mathrm{M} 1-\mathrm{M} 2}{\mathrm{M} 1} \times 100
$$

Where,

$\mathrm{M}_{1}$ is the mass in grams of the seeds before drying and $\mathrm{M}_{2}$ is the mass in grams of dried seeds.

Thousand-seed weight (TSW) was determined by count hundred seed from each treatment and multiplying by 10 . Harvested ears were placed on benches in the glasshouse under dry conditions and allowed to dry to $<12 \%$ moisture content. Yield components such as ear length (EL), ear diameter (ED), number of rows/ear (RN/E), kernel number/row (KN/R) and seed yield were recorded after dry the cobs at each harvesting stages. The length of ear was measured from the base to tip by using measuring scale and mean of six ears were expressed in $\mathrm{cm}$. The weight (yield) of the individual ear after drying to uniform moisture content $12 \%$ was recorded and the mean of six ears was expressed in grams per ear and later calculated as $\mathrm{kg} / \mathrm{ha}$.

The harvest index (HI) was computed as the ratio of seed yield to the total above ground. The following formula was used:

$$
\mathrm{HI}=\text { Seed yield/biological yield } \times 100
$$

The same procedure was followed for both the years. The total biomass (TB) and harvest index (HI) were determined at the end of physiological maturity in both seasons except in 2015/16 season where the dent stage of the maize was harvested and used for total biomass and harvest index under mid and late planting dates due to the invasion of wild pigs.

\subsection{Description of Statistical Analysis}

Bartlett's test was done to determine homogeneity of variances for all measured variables. Significant differences at $5 \%$ level of significance showed common variance among the planting dates in each season. Hence data for planting dates were pooled for subsequent analysis for crop phenology and yield components. Data collected were analyzed using spilt plot from GenStat ${ }^{\circledR}$ (Version 16, VSN International, UK) statistical package. Multiple comparison tests were done using Fisher's least significant difference (LSD) at the $5 \%$ level of significance.

\section{Results}

\subsection{Weather Conditions}

The weather data showed differences in the rainfall and temperatures measured across the three planting dates in each season. The weather data for 2014/15 season was consistent with the long-term weather data for Ukulinga site. However, weather data for $2015 / 16$ deviated marginally with an average temperature increase of $2.3{ }^{\circ} \mathrm{C}$ (November to March) from the observed annual mean maximum temperatures for the months. Comparing the two seasons, maximum and minimum temperatures were higher in $2015 / 16\left(28.1{ }^{\circ} \mathrm{C}\right.$ and $\left.15.6{ }^{\circ} \mathrm{C}\right)$ than $2014 / 15$ $\left(24.9^{\circ} \mathrm{C}\right.$ and $14.9^{\circ} \mathrm{C}$ respectively) which were not in conformity with the long-term maximum and minimum temperatures of $25.6^{\circ} \mathrm{C}$ and $16.9^{\circ} \mathrm{C}$ (Figure 1). These might have led to higher heat unit accumulation during $2015 / 16$ season especially at early $\left(1479.6^{\circ} \mathrm{cd}\right)$ and $\operatorname{mid}\left(1480.7^{\circ} \mathrm{cd}\right)$ planting dates and decreased during the late $\left(1213.1^{\circ} \mathrm{cd}\right)$ planting compared to $2014 / 15$ season where there was increasing trend from early, mid and late planting dates $\left(1289.4^{\circ} \mathrm{cd}, 1352.2^{\circ} \mathrm{cd}\right.$ and $1831.84^{\circ} \mathrm{cd}$ respectively).

Comparing the rainfall received during the early, mid and late planting dates in the two seasons, 2014/15 season $(407.9 \mathrm{~mm}, 371.6 \mathrm{~mm}$ and $267.2 \mathrm{~mm})$ received more distribution of rain than 2015/16 (444.8 $\mathrm{mm}, 360.7 \mathrm{~mm}$ and $208.4 \mathrm{~mm}$ respectively) (Figure 1). Almost 80\% of rainfall received during 2015/16 was received from 
January-March while the rest were sparingly distributed. Also, there were more days of no rainfall during the reproductive stage of the crops in 2015/16 than 2014/15 season (Figure 1). The observed results indicated high accumulation of heat unit and occurrence of water stress which hastened crop development and reduced the grain filling period in 2015/16. The weather data showed more favourable environmental conditions for the growth and development of maize in 2014/15 compared with 2015/16 though there were more occurrences of hail storms during the late vegetative stage of early planting dates in 2014/15 than 2015/16 which substantially reduced the plant leaf area and lead to yield loss in both seasons.
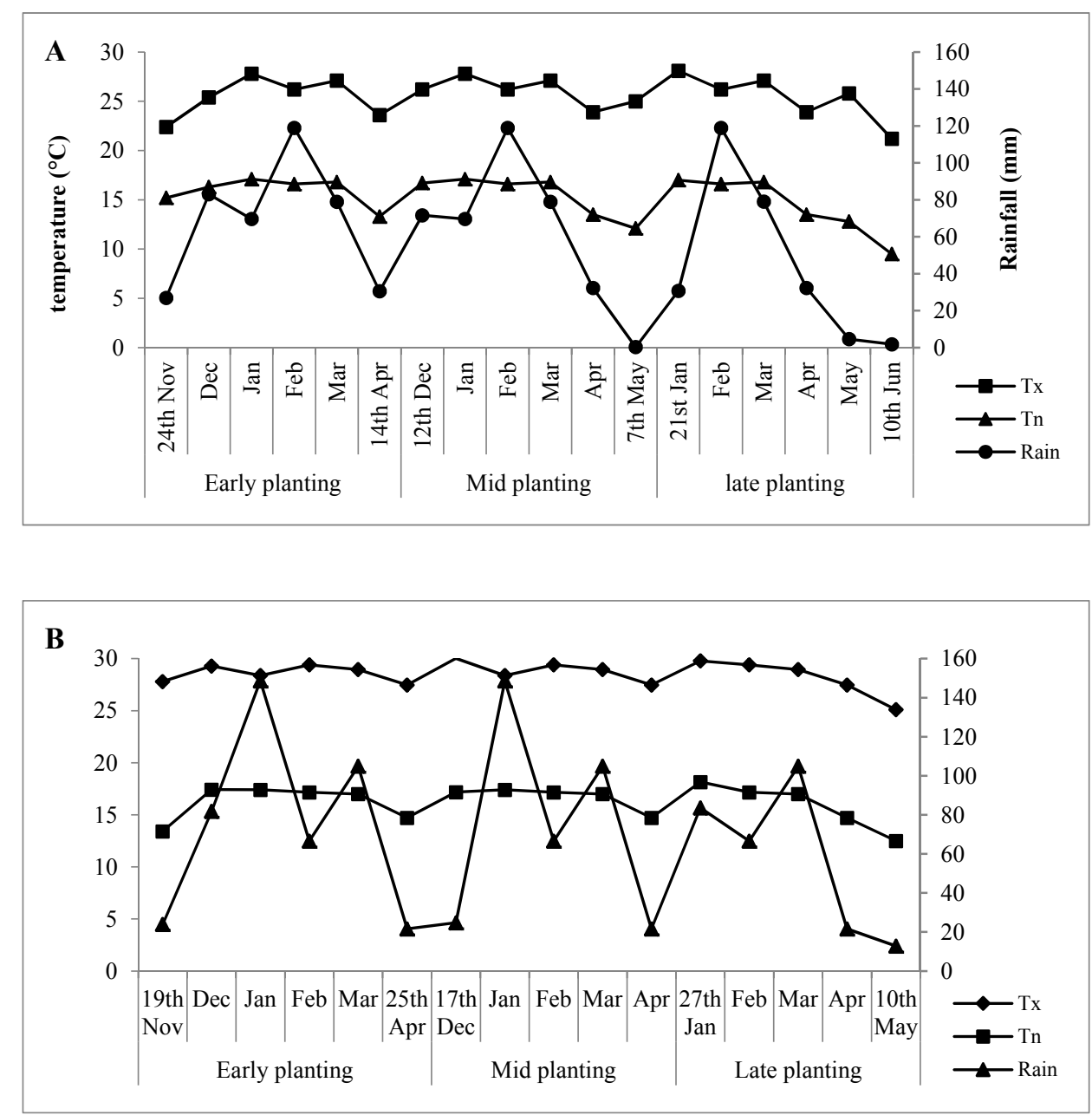

Figure 1. Variation in monthly rainfall (rain) and maximum $\left(\mathrm{T}_{\mathrm{x}}\right)$ and minimum $\left(\mathrm{T}_{\mathrm{n}}\right)$ temperatures $\left({ }^{\circ} \mathrm{C}\right)$ recorded during $\mathrm{A}=2014 / 15$ and $\mathrm{B}=2015 / 16$ planting seasons at Ukulinga, Pietermaritzburg

\subsection{Crop Phenology}

The time to reach $50 \%$ tasseling and silking were shown to be significantly affected by seasons and planting dates (Table 2). Time to reach 50\% tasseling and silking showed significant differences $(P<0.05)$ among the planting dates. Time to reach $50 \%$ tasseling and silking were statistical similar in early $\left(873.8^{\circ} \mathrm{cd}, 949.6^{\circ} \mathrm{cd}\right)$ and mid planting dates $\left(873.9^{\circ} \mathrm{cd}, 937.4^{\circ} \mathrm{cd}\right.$ while it was shortened in late planting $\left(835.1^{\circ} \mathrm{cd}, 898.7^{\circ} \mathrm{cd}\right)$ during 2014/15 season. Differences in trends were observed in $2015 / 16$ where plants from early planting $\left(892.8^{\circ} \mathrm{cd}\right.$, $\left.980.3^{\circ} \mathrm{cd}\right)$ had prolonged time in reaching tasseling and silking followed by plant from mid planting $\left(843.8^{\circ} \mathrm{cd}\right.$, $\left.904.1^{\circ} \mathrm{cd}\right)$ but late planting $\left(736.2^{\circ} \mathrm{cd}, 883.6^{\circ} \mathrm{cd}\right)$ had the shortest time (Table 2$)$. 
Table 2. Phenological stages in SC701 maize at different planting dates during the 2014/15 and 2015/16 seasons. Values in the same column sharing the same superscript letter are not significantly different $(\mathrm{P}<0.05)$

\begin{tabular}{|c|c|c|c|}
\hline Seasons (S) & Planting dates $(\mathrm{P})$ & TTT $\left({ }^{\circ} \mathrm{cd}\right)$ & TTS $\left({ }^{\circ} \mathrm{cd}\right)$ \\
\hline \multirow[t]{3}{*}{$2014 / 15$} & Early & $873.80 \mathrm{bc}$ & $949.60 \mathrm{~b}$ \\
\hline & Mid & $873.90 \mathrm{bc}$ & $937.40 \mathrm{~b}$ \\
\hline & Late & $835.10 \mathrm{~b}$ & $898.70 \mathrm{a}$ \\
\hline \multirow[t]{3}{*}{$2015 / 16$} & Early & $892.80 \mathrm{c}$ & $980.30 \mathrm{a}$ \\
\hline & Mid & $843.80 \mathrm{bc}$ & $904.10 \mathrm{~b}$ \\
\hline & Late & $736.20 \mathrm{a}$ & $883.60 \mathrm{a}$ \\
\hline $\operatorname{LSD}_{(\mathrm{P}<0.05)}$ Seasons & & 13.250 & 4.510 \\
\hline $\operatorname{LSD}_{(\mathrm{P}<0.05)}$ Planting dates & & 22.860 & 4.860 \\
\hline $\operatorname{LSD}_{(\mathrm{P}<0.05)}$ Seasons $\times$ Planting dates & & 27.440 & 6.270 \\
\hline
\end{tabular}

Note. TTT and TTS = time to reach $50 \%$ tasseling and silking respectively.

\subsection{Crop Growth and Physiology}

The interaction of planting dates and days after planting were not significant different $(P>0.05)$ for plant heights during 2014/15. But significant differences $(P<0.05)$ were observed in their interaction for leaf numbers During 2015/16, plant heights showed significant differences $(P<0.05)$ for interaction of planting dates and days after planting (Figure 2). Plant heights were lower during 2015/16 compared to 2014/15 and were more affected by the erratic rainfall during 2015/16.
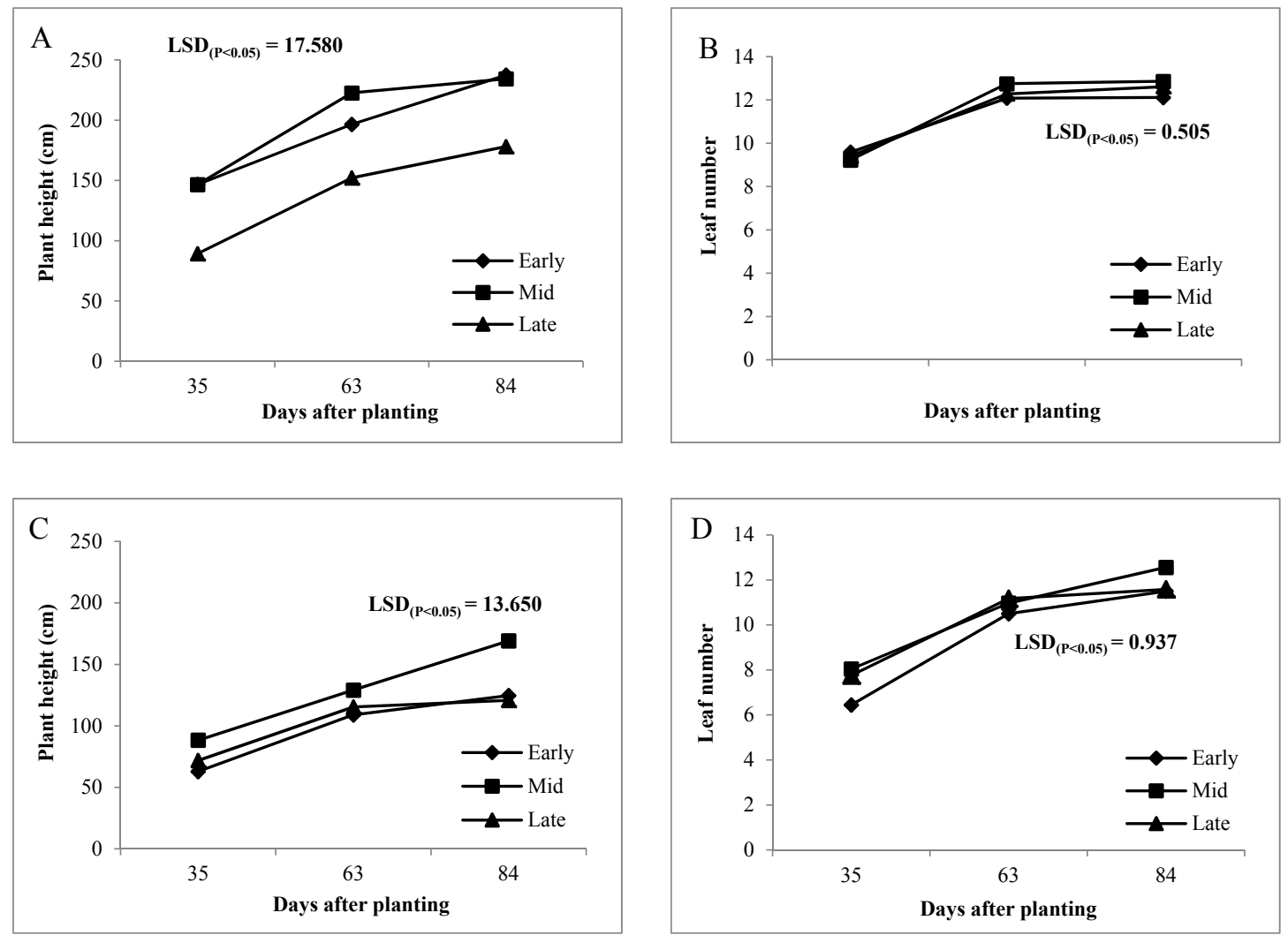

Figure 2. Plant height and leaf number of SC701 maize under different planting dates during (A and B) 2014/15 and (C and D) 2015/16 planting seasons. Early, mid and late represent early planting, mid planting and late planting 
The interaction of planting dates and time after silking (which was recorded as days after silking) were strongly influenced $(P<0.001)$ by plant chlorophyll content index $(\mathrm{CCI})$ in each planting seasons (Figure 3$)$. During 2014/15, there were significant differences $(P<0.05)$ in the interactions of planting dates and days after silking for CCI. It decreased linearly from seven to 58 days after silking. Also, CCI from early planting had the highest (48.90) relative to mid planting (42.40) and late planting (42.60). The CCI followed similar trends in each planting date. During 2015/16, plants CCI under early planting dates were significantly higher (49.51) relative to mid (43.82) and late planting (43.00). The CCI decreased from seven days after silking, then increased across 32 days after silking and later declined at 58 days after silking across the planting dates. There was no distinct trend in the measured CCI across days after silking, this might be due to inconsistent with the rate of distribution of precipitation (weather data).

The interaction of planting dates and days after silking were significantly $(P<0.001)$ influenced by stomatal conductance (gs) during 2014/15 (Figure 3). Stomatal conductance (gs) was lower under late planting relative to early planting conditions (Figure 3). The trend for lower gs was more distinct during 2015/16. The results showed decreasing trends for gs across days after silking and mid planting $>$ early planting $>$ late planting. During 2015/16, the interaction of planting dates and days after silking significantly $(P<0.05)$ influenced gs. Mid planting gave the highest gs among the planting dates from 18 DAS and decrease to 58 DAS. During both planting seasons, measurements of stomatal conductance were typically recorded during the reproductive stages of the crops (7 DAS-58 DAS).

There were highly significantly interactions $(P<0.001)$ among the planting dates and days after silking during both seasons with respect to LAI (Figure 3). During 2014/15, there was consistent with observations of plant height and leaf number across days after planting. Over time the mid planting date has higher leaf area index than early which might be due to occurrences of hail storm at late vegetative stage of the crop in early planting. Comparing the LAI from the three planting dates, leaf area index increases from 7 DAS to 18 DAS and then decrease from 32DAS till 58 DAS (Figure 3). During 2015/16, also mid planting date has higher LAI across days after silking, while the least was recorded at late planting date.
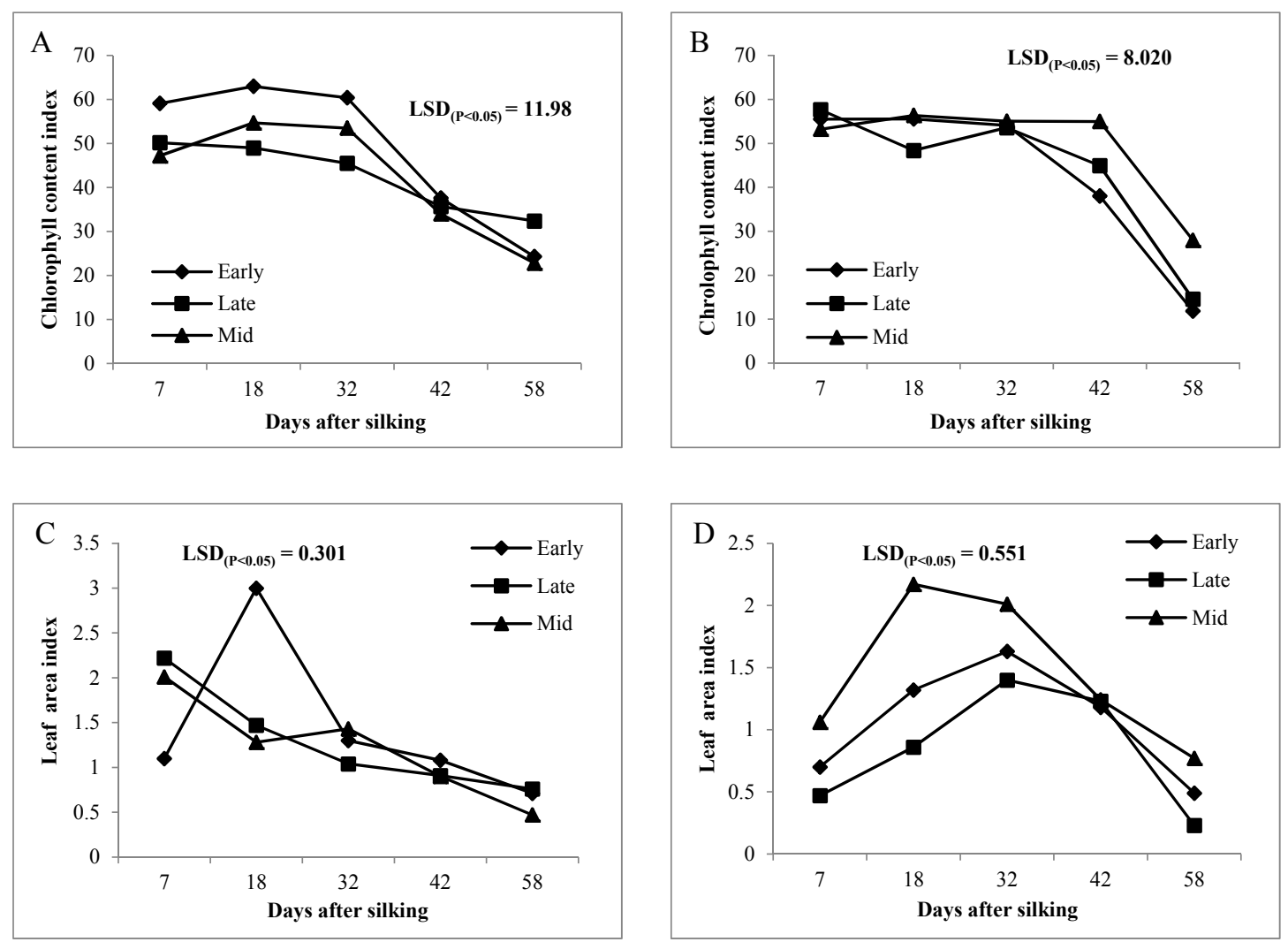

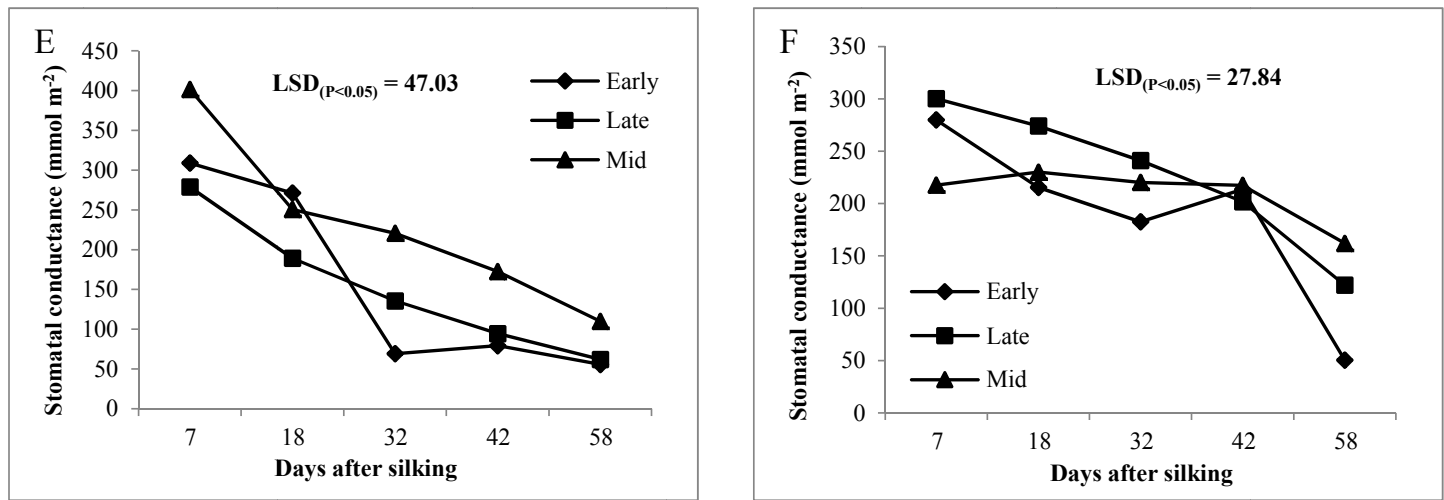

Figure 3. Chlorophyll content index, leaf area index and stomatal conductance of SC701 maize grown under early, mid and late planting dates during the (A, C and E) 2014/15 and (B, D and F) 2015/16 planting seasons

\subsection{Yield and Yield Components}

The total biomass and harvest index were significantly $(P<0.05)$ influenced by the planting dates during 2014/15. There were no statistical differences in mean values for biomass and harvest index under early and mid-planting dates (Figure 4). The harvest index obtained in $2015 / 16$ was significantly influenced $(P<0.001)$ by the planting dates. Likewise, the total biomass was significantly $(P<0.05)$ influenced by the planting dates. Total biomass and harvest index were significantly $(P<0.05)$ higher $(37.5 \%$ and $22 \%$ respectively) during $2014 / 15$ in comparison to $2015 / 16$. For the 2014/15, the total biomass and harvest index obtained from early and mid-planting performed similarly while late planting had the least biomass and harvest index. Overall, there were significant differences $(P<0.05)$ among the planting dates, seasons and their interactions for harvest index and highly significant difference $(P<0.001)$ occurred for total biomass (Figure 4$)$. Observed total biomass and harvest index for both seasons followed the observed growth patterns within each planting date.
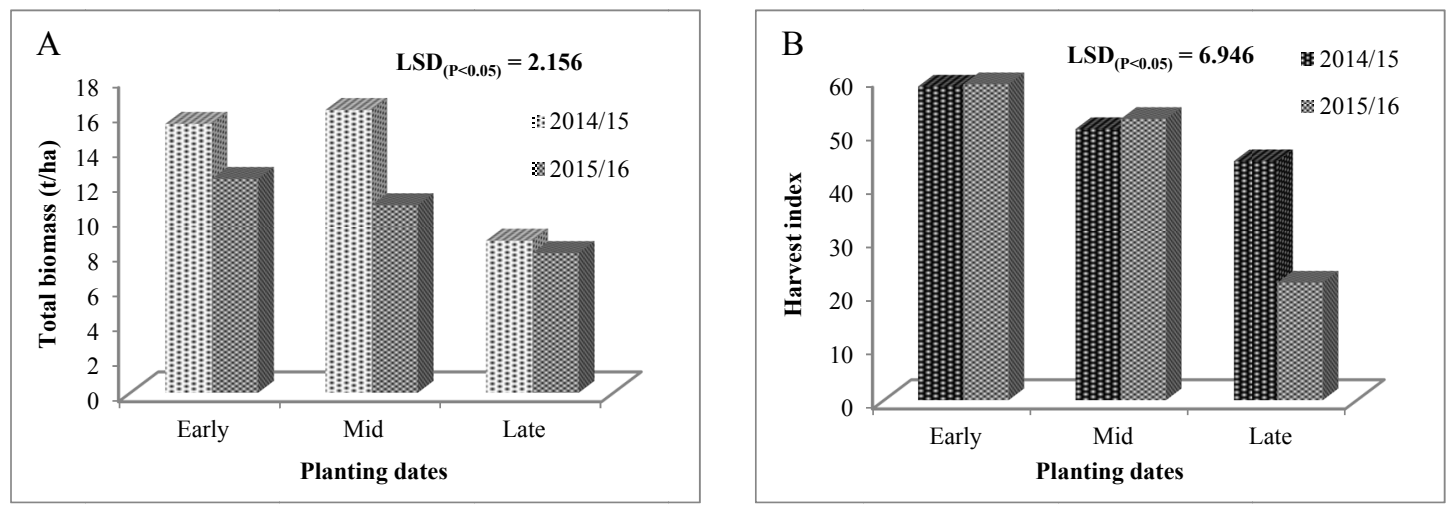

Figure 4. A: Total biomass of SC701 maize harvested at physiological matuirty under early, mid and late planting during 2014/15 and 2015/16 planting season; B: harvest index of SC701 maize at early, mid and late planting during 2014/15 and 2015/16 planting season

Results of yield components (grain yield, thousand seed weight, ear length, ear diameter, kernel number/row, row number/ear and seed moisture content) over the two planting seasons (2014/15 and 2015/16) showed much variability between seasons, harvesting stages and planting dates (Table 3). During 2014/15, grain yield and thousand seed weight were highly significantly influenced $(P<0.001)$ by the interactions of planting dates $\times$ harvesting stages. Also, ear length was significantly influenced $(P<0.05)$ by this interaction (Table 3$)$. During 2015/16 season, the interactions of planting dates $\times$ harvesting stages had strong effect $(P<0.05)$ on ear diameter, thousand seed weight and grain yield. This interaction significantly influenced $(P<0.001)$ seed moisture content. However, kernel number/row, kernel row/ear were not significantly influenced by this 
interaction (Table 3). The observed weather data for 2015/16 showed lesser distribution and lower-than-average rainfall received and higher atmospheric temperature.

During 2014/15, the ear length and thousand seed weight obtained at physiological maturity under early and mid-planting dates were statistically similar. Ear length obtained at dent stage under early planting was (21\%) higher than those from physiological maturity under late planting. During 2015/16, the ear diameter and thousand seed weight harvested under mid planting were higher than those harvested at physiological maturity under late planting. Also, similarity was observed in thousand seed weight and yield obtained at dent stage and physiological maturity under mid planting which was higher than those obtained under late planting.

Over all, planting dates significantly influenced $(P<0.001)$ ear length, thousand seed weight and had significant effect $(P<0.05)$ on ear diameter and kernel row/ear. The harvesting stages had significant effect $(P<0.001)$ on the yield components except the kernel number/row and kernel row/ear. Also, the interactions of planting dates $\times$ harvesting stages have significant effect $(P<0.05)$ on ear length, thousand seed weight, seed moisture content and significantly influenced $(P<0.001)$ the grain yield (Table 3$)$. The interactions of planting dates $\times$ harvesting stages $\times$ years significantly influenced $(P<0.05)$ the ear diameter, thousand seed weight and yield (Table 3$)$. All the yield components obtained in 2014/15 were higher compared with 2015/16 harvest.

Table 3. Yield and yield components of SC701 maize under different planting dates and harvesting stages during the 2014/15 and 2015/16 seasons. Values in the same column sharing the same superscript letter are not significantly different $(\mathrm{P}>0.05)$. Mean separation was performed using the LSD value for the planting date, harvesting stages and year interactions

\begin{tabular}{|c|c|c|c|c|c|c|c|c|c|c|c|c|c|c|c|}
\hline \multicolumn{2}{|l|}{ Treatments } & \multicolumn{2}{|c|}{$\mathrm{EL}(\mathrm{cm})$} & \multicolumn{2}{|c|}{$\mathrm{ED}(\mathrm{cm})$} & \multicolumn{2}{|c|}{ TSW (g) } & \multicolumn{2}{|c|}{$\mathrm{Y}(\mathrm{t} / \mathrm{ha})$} & \multicolumn{2}{|c|}{$\mathrm{KN} / \mathrm{R}$} & \multicolumn{2}{|c|}{$\mathrm{KR} / \mathrm{E}$} & \multicolumn{2}{|c|}{$\mathrm{MC}$} \\
\hline $\begin{array}{l}\text { Planting } \\
\text { dates (P) }\end{array}$ & $\begin{array}{l}\text { Harvesting } \\
\text { stages }(\mathrm{H})\end{array}$ & $1^{\text {st }}$ year & $2^{\text {nd }}$ year & $1^{\text {st }}$ year & $2^{\text {nd }}$ year & $1^{\text {st }}$ year & $2^{\text {nd }}$ year & $1^{\text {st }}$ year & $2^{\text {nd }}$ year & $1^{\text {st }}$ year & $2^{\text {nd }}$ year & $1^{\text {st }}$ year & $2^{\text {nd }}$ year & $1^{\text {st }}$ year & $2^{\text {nd }}$ year \\
\hline Early & Milk stage & $28.80 \mathrm{~cd}$ & $25.00 \mathrm{a}$ & $7.69 \mathrm{a}$ & $7.88 \mathrm{~cd}$ & $269.20 \mathrm{a}$ & $331.50 \mathrm{a}$ & $2.19 \mathrm{~b}$ & $2.44 \mathrm{ab}$ & $50.00 \mathrm{a}$ & $33.75 \mathrm{a}$ & $13.00 \mathrm{a}$ & $12.50 \mathrm{a}$ & $77.00 \mathrm{a}$ & $80.10 \mathrm{~d}$ \\
\hline Mid & & $24.52 b$ & $22.00 \mathrm{a}$ & $7.50 \mathrm{a}$ & $7.56 \mathrm{abc}$ & $270.20 \mathrm{a}$ & $430.00 \mathrm{~b}$ & $1.97 \mathrm{a}$ & $2.67 \mathrm{~b}$ & $50.50 \mathrm{a}$ & $38.87 \mathrm{a}$ & $13.00 \mathrm{a}$ & $13.00 \mathrm{a}$ & $71.59 \mathrm{a}$ & $77.39 \mathrm{~d}$ \\
\hline Late & & $23.10 \mathrm{ab}$ & $19.12 \mathrm{a}$ & $6.81 \mathrm{a}$ & $7.00 \mathrm{a}$ & $238.90 \mathrm{a}$ & $364.50 \mathrm{a}$ & $2.26 \mathrm{~b}$ & $1.93 \mathrm{a}$ & $46.00 \mathrm{a}$ & $30.37 \mathrm{a}$ & $13.08 \mathrm{a}$ & $12.25 \mathrm{a}$ & $81.70 \mathrm{a}$ & $80.10 \mathrm{~d}$ \\
\hline Early & Dent stage & $29.75 \mathrm{~d}$ & $23.50 \mathrm{a}$ & $8.63 \mathrm{a}$ & $7.06 \mathrm{ab}$ & $611.50 \mathrm{c}$ & $603.50 \mathrm{~d}$ & $3.88 \mathrm{c}$ & $4.27 \mathrm{~d}$ & $51.00 \mathrm{a}$ & $34.75 \mathrm{a}$ & $12.50 \mathrm{a}$ & $12.00 \mathrm{a}$ & $48.59 \mathrm{a}$ & $59.12 \mathrm{c}$ \\
\hline Mid & & $27.58 \mathrm{c}$ & $22.62 \mathrm{a}$ & $8.24 \mathrm{a}$ & $8.13 \mathrm{~cd}$ & $670.40 \mathrm{~d}$ & $697.80 \mathrm{e}$ & $4.61 \mathrm{c}$ & $5.12 \mathrm{e}$ & $50.50 \mathrm{a}$ & $38.67 \mathrm{a}$ & $12.42 \mathrm{a}$ & $12.75 \mathrm{a}$ & $42.19 \mathrm{a}$ & $48.33 b$ \\
\hline Late & & $22.75 \mathrm{a}$ & $16.50 \mathrm{a}$ & $7.56 \mathrm{a}$ & $7.50 \mathrm{abc}$ & $414.50 \mathrm{~b}$ & $512.20 \mathrm{c}$ & $2.26 \mathrm{~b}$ & $2.55 \mathrm{ab}$ & $40.00 \mathrm{a}$ & $27.00 \mathrm{a}$ & $12.75 \mathrm{a}$ & $12.37 \mathrm{a}$ & $56.92 \mathrm{a}$ & $54.34 \mathrm{c}$ \\
\hline Early & $\begin{array}{l}\text { Physiological } \\
\text { Maturity }\end{array}$ & $29.00 \mathrm{~cd}$ & $19.50 \mathrm{a}$ & $8.81 \mathrm{a}$ & $8.50 \mathrm{~d}$ & $698.40 \mathrm{~d}$ & $766.50 \mathrm{f}$ & $6.01 \mathrm{~d}$ & $4.96 \mathrm{e}$ & $51.12 \mathrm{a}$ & $28.25 \mathrm{a}$ & $13.38 \mathrm{a}$ & $12.08 \mathrm{a}$ & $29.76 \mathrm{a}$ & $32.64 \mathrm{~b}$ \\
\hline Mid & & $28.50 \mathrm{~cd}$ & $17.94 \mathrm{a}$ & $8.50 \mathrm{a}$ & $8.65 \mathrm{~d}$ & $686.40 \mathrm{~d}$ & $756.80 \mathrm{e}$ & $5.83 \mathrm{~d}$ & $5.28 \mathrm{e}$ & $49.75 \mathrm{a}$ & $33.12 \mathrm{a}$ & $12.17 \mathrm{a}$ & $12.71 \mathrm{a}$ & $24.17 \mathrm{a}$ & $24.18 \mathrm{a}$ \\
\hline Late & & $\begin{array}{l}23.40 \mathrm{ab} \\
(P<0.05)\end{array}$ & $\begin{array}{l}13.44 \mathrm{a} \\
(P>0.05)\end{array}$ & $\begin{array}{l}7.44 \\
(P>0.05)\end{array}$ & $\begin{array}{l}7.87 \mathrm{bcd} \\
(P<0.05)\end{array}$ & $\begin{array}{l}408.50 \mathrm{~b} \\
(P<0.001)\end{array}$ & $\begin{array}{l}610.20 \mathrm{~d} \\
(P<0.05)\end{array}$ & $\begin{array}{l}3.94 \mathrm{c} \\
(P<0.001\end{array}$ & $\begin{array}{l}3.77 \mathrm{c} \\
(P<0.05)\end{array}$ & $\begin{array}{l}41.75 a \\
(P>0.05)\end{array}$ & $\begin{array}{l}23.03 \mathrm{a} \\
(P>0.05)\end{array}$ & $\begin{array}{l}12.88 \mathrm{a} \\
(P>0.05)\end{array}$ & $\begin{array}{l}12.15 \mathrm{a} \\
(P>0.05)\end{array}$ & $\begin{array}{l}36.69 \mathrm{a} \\
(P>0.05)\end{array}$ & $\begin{array}{l}24.66 \mathrm{a} \\
(P<0.001)\end{array}$ \\
\hline Lsd value & & 1.714 & 2.825 & 0.613 & 0.815 & 58.220 & 75.06 & 1.004 & 0.680 & 4.472 & 8.390 & 1.196 & 1.205 & 6.701 & 5.490 \\
\hline $\mathrm{PD}^{1}$ & & $(P<0.001)$ & & $(P<0.05)$ & & $(P<0.001)$ & & $(P<0.001)$ & & $(P>0.05)$ & & $(P<0.05)$ & & $(P>0.05)$ & \\
\hline Lsd value & & 0.766 & & 0.410 & & 33.010 & & 0.305 & & 4.298 & & 0.482 & & 3.911 & \\
\hline $\mathrm{H}^{1}$ & & $(P<0.001)$ & & $(P<0.001)$ & & $(P<0.001)$ & & $(P<0.001)$ & & $(P>0.05)$ & & $(P>0.05)$ & & $(P<0.001)$ & \\
\hline & & 1.195 & & 0.410 & & 29.76 & & 0.305 & & 2.601 & & 0.574 & & 3.139 & \\
\hline Year $^{1}$ & & $(P<0.001)$ & & $(P>0.05)$ & & $(P<0.001)$ & & $(P<0.001)$ & & $(P<0.001)$ & & $(P>0.05)$ & & $(P<0.001)$ & \\
\hline Lsd value & & 0.926 & & 0.240 & & 21.310 & & 0.279 & & 2.367 & & 0.384 & & 1.900 & \\
\hline $\mathrm{P} \times \mathrm{H}^{1}$ & & $(P<0.05)$ & & $(P>0.05)$ & & $(P<0.05)$ & & $(P<0.001)$ & & $(P>0.05)$ & & $(P>0.05)$ & & $(P<0.05)$ & \\
\hline Lsd value & & 1.919 & & 0.508 & & 23.520 & & 0.742 & & 5.212 & & 0.896 & & 5.488 & \\
\hline $\mathrm{P} \times \mathrm{H} \times \mathrm{Y}^{1}$ & & $(P>0.05)$ & & $(P<0.05)$ & & $(P<0.05)$ & & $(P<0.05)$ & & $(P>0.05)$ & & $(P>0.05)$ & & $(P>0.05)$ & \\
\hline Lsd value & & 2.264 & & 0.658 & & 65.480 & & 0.923 & & 7.005 & & 1.178 & & 6.632 & \\
\hline
\end{tabular}

Note. $\mathrm{EL}=$ ear length, $\mathrm{ED}=$ ear diameter, $\mathrm{TSW}=$ thousand seed weight, $\mathrm{Y}=$ yield, $\mathrm{KN} / \mathrm{R}=$ kernel number/row, $\mathrm{KR} / \mathrm{E}=$ kernel row number/ear, $\mathrm{MC}=$ seed moisture content and $1=$ Statistics refer to the comparison between the $2014 / 15$ and $2015 / 16$ planting seasons for the three planting dates. 


\section{Discussion}

Weather conditions that are optimal for production of maize are likely to be less predictable in future due to variability in weather conditions and may have resultant effect on the stage of maturity at harvest (Blignaut et al., 2009). Furthermore, recent findings indicated the need for long term adaptation strategies to ensure food security in response to climate change (Ziervogel et al., 2014). This finding purposely focused on a maize SC701 cultivar that is widely grown across all levels of agricultural systems in southern Africa, from subsistence through to small-scale and industrial agriculture.

This current study showed that the increase in atmospheric temperature and below average rainfall experienced made 2015/16 season a drier season compared to 2014/15 season. This might have caused stress in the plant growth and metabolic activities. Early and mid-planting have averagely warm temperature and rainfall necessary for optimal growth and development while drop in temperature and rainfall during the late planting resulted in deficit GDD which hasten flowering in late planting at both season. This might have cause reduction in partitioning of assimilates during grain filling and led to a decline in yield and yield-related parameters in both seasons. Also, the observed association of leaf physiological parameters (CCI and gs) are basically related with photosynthetic potential of the plants. Early planting in 2014/15 and mid planting in 2015/16 seasons experienced sufficient distribution of rainfall majorly in their growth and developmental stages which enhanced stomatal conductivity. Manzoni et al. (2011) reported that high stomatal increased $\mathrm{CO}_{2}$ diffusion inside the leaf thus improving photosynthetic rate. Low stomatal conductivity in late planting at both seasons might be due to stomatal closure which is widely thought to be plant's first line of defence in response to developing water stress. High stomatal conductance and chlorophyll content index in plants under early and mid-planting increased the photosynthetic capacity, indicating that the plants have higher capacity to allocate more assimilates to developing kernels. The decreased in chlorophyll contents under extreme weather conditions were consistent with Anjum et al. (2011) who reported the reduced chlorophyll contents under progressive drought stress in maize, though emphasises was not on plant chlorophyll contents different planting dates.

The differences in planting dates led to variation in canopy stature. On average, early planted and mid planted maize performed similarly having taller plants, greater leaf number and LAI relative to late planting maize thus producing large canopy earlier in their planting seasons which optimally utilize solar radiation for photosynthesis. The lower plant growth observed under late planting across days after planting might have been due to limited water availability for plant use under extreme weather condition which reduced photosynthetic rate, $\mathrm{CO}_{2}$ assimilation and fixation. Similar findings showing reduction in plant height, leaf number and LAI in maize have been reported in the literature (Anjum et al., 2011; Blum, 2005; Tardieu, 2014). This implied that as the planting date of maize is delayed the probability of having high canopy stature will be reduced in any planting seasons.

Planting under different environmental conditions influences the phenological stages in maize. The results of crop phenology showed clearer responses to differences in rainfall distribution and temperatures received at each planting date and season. The accumulated heat units for tasseling and silking were higher under warm temperature and sufficient availability water for plant uses (early and mid-planting) while it was shortened in late planting. Thereby, causing maize planted lately to flower earlier because of deficit in accumulated heat units as compared to plants from early and mid-planting dates. Parthasarathi et al. (2013) reported similar finding that heat unit accumulation at the time of flowering leads to early flowering in cereals. Also, Hatfield et al. (2015) explained that limited water availability to plant during flowering has an adverse effect on its physiological status causing decline in photosynthetic rates and plant growth. This current study observed that plant from late planting date had the lowest grain yield.

Results of total biomass and harvest index obtained in both seasons showed similarities between early and mid-planting while lower trends were observed under late planting dates which were consistent with the trend observed for stomatal conductance, chlorophyll content and plant growth parameters. This explains why researchers have previously ascribed biomass accumulation to source strength and sink's capacity which are seriously reduced by limited soil water (Aslam et al., 2015; Gambín et al., 2006).

The yield components affected by the interaction of maturity stage at harvest and planting dates were grain yield, ear length, ear diameter and thousand seed weight. Ear length, ear diameter and thousand seed weight obtained at dent stage (42 DAS) under moderate and favourable weather conditions performed higher than its counterpart from physiological maturity (58 DAS) which experienced adverse weather conditions (late planting) during its growth and developmental stages. A stressful environment during grain filling could have caused the reduction in thousand seed weight which would have influenced the ear diameter. The canopy stature determined the rate of light interception received at each planting dates which greatly influenced the plant source-sink relationships and 
thus seed weight (Gambín et al., 2006; Novacek et al., 2013). This implied that seed weight of kernel harvested relatively to physiological maturity (42 DAS) under favourable growing condition would be heavier than its counterpart at physiological maturity but under extreme weather conditions.

Planting dates and maturity stages at harvest have strong effect on grain yield though, similarity was observed in grain yield harvested at dent stage and physiological maturity under mid planting date (moderately favourable weather conditions). This might be due to decline in the rate of remobilization of photosynthetic assimilate to the kernel as it's tends toward physiological maturity. Given the possibility of obtaining reasonable yield when harvesting commence at dent stage.

Harvesting too early at milk stage (18 DAS) due to prevailing extreme weather conditions should not be encouraged because it led to the highest yield loss because the plant had the least photosynthates at this stage as express in low thousand seed weight and grain yield except if it meant for silage production. The continuous decrease in the seed moisture content from milk stage to physiological maturity indicated increase in biomass accumulation towards later stage of maturity (Aslam et al., 2015). Planting date had greater influence on seed moisture content in the drier season and late planting date than in warm season under early and mid-planting date. This influence could be due to the increase in the atmospheric temperature in drier season which hasten reduction in the seed moisture content. Kernel number/row and kernel row/ear were not affected by planting dates and harvesting stages. This could be attributed to their strong dependence on their genetics make up and could be only hinder by severe environmental stresses. This current research agreed with Modi and Greenfield (2010) reported that reduction in grain yield experienced with extreme weather conditions was due to increase in the duration of the grain-filling and decrease in the rate of grain filling which were insufficient to prevent grain yield loss. Also, Hasanuzzaman et al. (2013) reported that the accumulated high temperatures could have caused an array of morphological, physiological and biochemical changes within plant such as decrease in the number of grains and kernel weight. The improvement in grain yield of the early and mid-planted maize might be due to the increase in plant growth under adequate soil moisture which enabled it to reach post-anthesis stage during the hottest summer periods and escaped greater water deficit compared with later planted maize where its nutrient availability, uptake, transport and grain filling coincided with extreme temperatures and water deficit.

\section{Conclusion}

Low rainfall distribution and extreme temperatures cannot be predicted in any specific season or stage of plant growth and development. Evaluating the response of maize to a changing climate can provide viable options for enhancing adaptive capacity of small holder farmers in these areas. This current finding showed that the risk of yield losses due to adverse weather conditions decrease as maize nears physiological maturity. The weather conditions at each planting date and stages of maturity at harvest have a considerable effect on the rate of grain filling and yield. Maize yield obtained in eary harvest at late dent stage under moderately favourable growing conditions out performed it counterpart maize yield that reached physiological maturity under extreme weather conditions. Also, there is high risk that maize plant would not be able to reach physiological maturity with delayed planting or under adverse weather condition. Planting dates affect plant growth, development and yield depending on environmental conditions and stages of maturity at harvest.

\section{References}

Anjum, S., Farooq, M., Wang, L., Xue, L., Wang, S., Wang, L., Zhang, S., \& Chen, M. (2011). Gas exchange and chlorophyll synthesis of maize cultivars are enhanced by exogenously-applied glycinebetaine under drought conditions. Plant Soil Environ., 57, 326-331.

Anwar, M. J., Muhammad, B. Y., Bader, A. A., Abdulghani, M., Mahmood, D., \& Haider, M. (2015). An insight into the scientific background and future perspectives for the potential uses of melatonin. Egyptian Journal of Basic and Applied Sciences, 2, 139-152. https://doi.org/10.1016/j.ejbas.2015.05.003

ARC. (2014). Agricultural Research Council Annual Report.

Aslam, M., Maqbool, M. A., \& Cengiz, R. (2015). Drought Stress in Maize (Zea mays L.): Effects, Resistance Mechanisms, Global Achievements and Biological Strategies for Improvements. University of Agriculture Faisalabad Pakistan. https://doi.org/10.1007/978-3-319-25442-5

Beiragi, M. A., Khorasani, S. K., Shojaei, S. H., Dadresan, M., Mostafavi, K., \& Golbashy, M. (2011). A study on effects of planting dates on growth and yield of 18 corn hybrids (Zea mays L.). American Journal of Experimental Agriculture, 1, 110. https://doi.org/10.9734/AJEA/2011/339

Blignaut, J., Urckermann, L., \& Aronson, J. (2009). Agriculture production's sensitivity to changes in climate in South Africa. South African Journal of Science, 105, 61-71. https://doi.org/10.4102/sajs.v105i1/2.4 
Blum, A. (2005). Drought resistance, water-use efficiency, and yield potential-Are they compatible, dissonant, or mutually exclusive? Australian Journal of Agricultural Research, 56, 1159-1168. https://doi.org/ 10.1071/AR05069

Coulter, J. (2012). Planting Date Considerations for Corn. In U. O. M. Extension (Ed.), Minnesota Crop News. Minnesota.

Darby, H., \& Lauer, J. (2002). Critical Stages in the Life of a Corn Plant.

Daynard, T. B. (1972). Relationships among black layer formation, grain moisture percentage, and heat unit accumulation in corn. Agronomy Journal, 64, 716-719. https://doi.org/10.2134/agronj1972.000219620064 $00060003 \mathrm{x}$

FAO. (2015). World reference base for soil resources 2014. Food and Agriculture Organization of the United Nations, Rome, Italy.

Gambín, B. L., Borrás, L., \& Otegui, M. E. (2006). Source-sink relations and kernel weight differences in maize temperate hybrids. Field Crops Research, 95, 316-326. https://doi.org/10.1016/j.fcr.2005.04.002

Good, D., Newton, J., \& Irwin, S. (2015). Early Planting and 2015 Corn Yield Prospects: How Much of an Increase? Farmdoc Daily, 5.

Hasanuzzaman, M., Nahar, K., Alam, M. M., Roychowdhury, R., \& Fujita, M. (2013). Physiological, biochemical, and molecular mechanisms of heat stress tolerance in plants. International Journal of Molecular Sciences, 14, 9643-9684. https://doi.org/10.3390/ijms14059643

Hatfield, J., Prueger, L., \& John, H. (2015). Temperature extremes: Effect on plant growth and development. Weather and Climate Extremes, 10, 4-10. https://doi.org/10.1016/j.wace.2015.08.001

Henning, F., Jacob, J. R., Mertz, L. E., \& Peske, S. (2011). Qualidade sanitária de sementes de milho em diferentes estádios de maturação. Revista Brasileira de Sem, 33, 316-321. https://doi.org/10.1590/ S0101-31222011000200014

Hoegemeyer, T. (2013). In IOAAN Resources (Ed.), Effects of cool late July/early August on corn yield and maturity. UNL CropWatch, University of Nebraska-Lincoln.

Jacob Junior, E. A., Mertz, L. M., Henning, F. A., Peske, S. T., Villela, F. A., \& Labbé, L. M. B. (2014). Ideal seeds harvest moment of different maize hybrids. Ciência Rural, 44, 253-260. https://doi.org/10.1590/ S0103-84782014000200010

Kgasago, H. (2006). Effect of planting dates and densities on yield and yield components of short and ultra-short growth period maize (Zea mays L.). University of Pretoria.

Manzoni, S., Vico, G., Katul, G., Fay, P. A., Polley, W., Palmroth, S., \& Porporato, A. (2011). Optimizing stomatal conductance for maximum carbon gain under water stress: A meta-analysis across plant functional types and climates. Functional Ecology, 25, 456-467. https://doi.org/10.1111/j.1365-2435.2010.01822.x

McMaster, G. S., \& Wilhelm, W. (1997). Growing degree-days: One equation, two interpretations. Agricultural and Forest Meteorology, 87, 291-300. https://doi.org/10.1016/S0168-1923(97)00027-0

Modi, A. T., \& Greenfield, P. L. (2010). Crop physiology: A perspective for southern Africa. South Africa Journal of Plant and Soil, 27, 37-48. https://doi.org/10.1080/02571862.2010.10639969

Nafziger, E. (2008). In UOI Extension (Ed.), Thinking About Corn Planting Date and Population. University of Illinois Extension, Illinois.

Nielsen (Bob), R. L. (2013). Grain Fill Stages in Corn. Agronomy Dept., Purdue Univ., West Lafayette.

Novacek, M. J., Mason, S. C., Galusha, T. D., \& Yaseen, M. (2013). Twin rows minimally impact irrigated maize yield, morphology, and lodging. Agronomy Journal, 105, 268-276. https://doi.org/10.2134/ agronj2012.0301

Parthasarathi, T., Velu, G., \& Jeyakumar, P. (2013). Impact of Crop Heat Units on Growth and Developmental Physiology of Future Crop Production: A Review. Journal of Crop Science and Technology, 2, 1-11.

Pierce, L. L., \& Running, S. W. (1988). Rapid estimation of coniferous forest leaf area index using a portable integrating radiometer. Ecology, 69, 1762-1767. https://doi.org/10.2307/1941154

Ritchie, S. W., Hanway, J. J., \& Benson, G. O. (1992). How a corn plant develops. Iowa State University, Iowa. 
Sárvári, M., \& Futó, Z. (2000). Correlation between the sowing date, yield and grain moisture content of maize hybrids on chernozem soil. Debreceni Egyetem Agrártudományi Közlemények Journal, 1, 32-41.

SCWG. (2009). In DOA Development (Ed.), Soil calssification: A taxonomic system for South Africa (pp.139-151). Soil Classification Working Group, Pretoria.

Smith, B. (2006). The Farming Handbook. University of KwaZulu-Natal Press, Kwazulu-Natal.

Tardieu, F. (2014). Plant response to environmental conditions: Assessing potential production, water demand, and negative effects of water deficit. Drought phenotyping in crops: From theory to practice, 42.

Ziervogel, et al. (2014). Climate change impacts and adaptation in South Africa. WIREs Climate Change.

\section{Copyrights}

Copyright for this article is retained by the author(s), with first publication rights granted to the journal.

This is an open-access article distributed under the terms and conditions of the Creative Commons Attribution license (http://creativecommons.org/licenses/by/4.0/). 